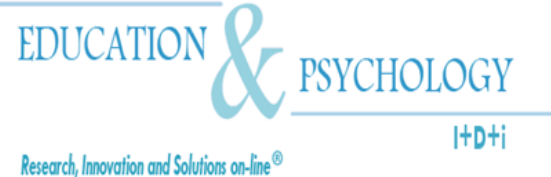

Electronic Journal of Research

in Educational Psychology

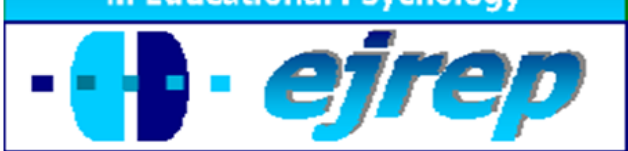

Editorial EOS

\title{
Influence of Computer Anxiety and Knowledge on Computer Utilization of Senior Secondary School Students
}

\author{
Rafiu Ademola Olatoye
}

Institute of Education, Olabisi Onabanjo University,

Ago-Iwoye, Ogun State

\section{Nigeria}

Correspondence: Rafiu Ademola Olatoye. Institute of Education, Olabisi Onabanjo University, Ago-Iwoye, Ogun State, Nigeria.. E-mail: kingdemola@yahoo.com

(C) Education \& Psychology $\mathrm{I}+\mathrm{D}+\mathrm{i}$ and Editorial EOS (Spain) 


\begin{abstract}
Introduction. The increase in computer usage is rapid and has also generated new challenges. This study investigated the influence of computer anxiety and knowledge on computer utilization among senior secondary school students in Ogun State, Nigeria.
\end{abstract}

Method. A sample of four hundred students randomly selected from twenty secondary schools participated in the study.

Results. Computer anxiety and knowledge when taken together significantly predicted computer utilization ( $\mathrm{R}$ Square $=0.079, \mathrm{p}<0.05$ ). There was significant relationship between computer knowledge and computer utilization $(\mathrm{r}=+0.276, \mathrm{p}<0.05)$. There was no significant difference between male and female students' computer anxiety $(t=1.005, p>0.05)$

Conclusion and Recommendations. Computer anxiety is a negative psychological construct that does not in anyway enhance computer utilisation. Computer knowledge however has positive relationship with computer utilization. Thus for Nigerian government to realise the Millennium Development Goals and improve computer literacy level, there is need to deliberately encourage computer teaching.

Keywords: Computer anxiety, computer knowledge, computer utilization, ICT, students.

Received: 05/11/09 Initial Acceptance: 05/22/09 Final Acceptance: 07/06/09 


\section{Influencia de la ansiedad ante los ordenadores y el conocimiento de su uso en estudiantes de secundaria}

\section{Resumen}

Introducción. El uso de ordenadores se ha expandido con rápidez y también ha generado nuevos retos. Este estudio investiga la influencia de la ansiedad ante los ordenadores, y el conocimiento de su uso en estudiantes del último ciclo de secundaria en el Estado de Ogun, Nigeria.

Método. Participó en el estudio una muestra de cuatrocientos alumnos elegidos aleatoriamente de entre veinte centros de educación secundaria.

Resultados. La ansiedad ante los ordenadores y el conocimiento de su uso, considerados en conjunto, predecían la utilización del ordenador de forma significativa (R Cuadrado=0,079, $\mathrm{p}<0.05$ ). Existía una relación significativa entre el conocimiento de ordenadores y su utilización $(r=+0,276, p<0.05)$. No hubo diferencias significativas entre hombres y mujeres en cuanto a la ansiedad ante los ordenadores $(\mathrm{t}=1,005, \mathrm{p}>0.05)$

Conclusión y recomendaciones. La ansiedad ante los ordenadores es un constructo psicológico negativo que, de ninguna manera, favorece la utilización del ordenador. El conocimiento, sin embargo, está relacionado de forma positiva con la utilización del ordenador. Por lo tanto, para que el gobierno nigeriano realice sus metas de Desarrollo para el Milenio, mejorando el nivel de alfabetización digital, existe una necesidad de fomentar deliberadamente la enseñanza del uso de ordenadores.

Palabras clave: Ansiedad ante los ordenadores, conocimiento del uso de ordenadores, utilización del ordenador, TIC, estudiantes.

Recibido: 11/05/09 Aceptación inicial: 22/05/09 Aceptación final: 06/07/09 


\section{Introduction}

The need for computer education in schools cannot be over emphasized. This is because computers make things easy in our society. Almost everything has to do with computer, any person at this age of ours, be it an adult or a child who lacks knowledge of computer could be regarded as an incomplete human being. Computer Information Communication Technology has become an integral part of our society (Chiemeke, 2004). Exposure to this new medium gives one the opportunity to acquire unlimited amount of knowledge and a chance to communicate with others around the world. Information Communication Technology (ICT) is now a fast way to create, send and consume new information. Computer-Mediated Communication (CMC) extends mental capabilities and enhances our intellect (Backer, 1994).

Computers have now been accepted " unconditionally " as an integral part of our entire educational system. The increase in computer usage is rapid and has also generated new challenges. In fact, one of the most dynamic and innovative areas of growth in education is the utilization of computer technology. Shinn (2001) asserted that for a school to remain competitive it also must adapt to changes and be innovative with its use of computer. She further stated that, despite income, school budgets and location, soon all students will have access to information through the internet.

Today, the internet is being used as a payment method; telecommunication traffic is also possible through the computer video and audio services (Jonah, 2007). Technology can play a vital role in helping students meet higher standard and perform at increased levels by promoting alternative, innovative approaches to teaching and learning (George, 2000). Email is taking the place of inter-office correspondence. Business is rapidly becoming computerized. Students and workers need to be comfortable with computers now more than ever. As the academic and business environment continues to move forward in computer technology, the gap is widening between development in computer technology and those people who experience computer anxiety. As a matter of fact, the terms, "Computer Phobia" and "Computer Anxiety" are used in the literature vocabulary due to teacher and student resistance to computer use. The causes of this resistance according to Nickerson (1981) are not unconnected with feelings of stupidity, fear of obsolescence, fear of the unfamiliar operations done with computers and the thought that computers have a dehumanizing effect. 
Psychological factors are important in educational research; they have been linked with improving student academic performance (Fernandez-Castillo \& Gutierrez, 2009; Ruiz \& Lupianez, 2009). Psychological factors are also important in correcting deviant behaviours of young people (Scandroglio, Lopez-Martinex, Jose, 2008). Therefore, in considering computer utilization, it is important to consider psychological factor like computer anxiety. Studies have shown that computer anxiety, lack of confidence, and lack of enjoyment influence both the acceptance of computers and their use as teaching and learning tools (Fletcher \& Deeds, 1994; Gressard \& Loyd, 1986). The need to therefore disabuse the mind of both teachers and their students from such fears and replace these misconceptions with confidencebuilding measures is more than ever paramount. In this regard, computer ownership and computer experience are two very important and interrelated factors that can help in mitigating fear and anxiety about computers from the minds of teachers and students. The teacher if guaranteed total access and freedom to experiment with the use of a computer as a teaching tool, then comes the reciprocal outcome of computer experience that provides the technical know-how and the intellectual ability to manipulate and discover the pedagogical power of the computer. The importance of knowledge and experience in the use of computer have been echoed and reiterated in many studies. Loyd and Gressard (1984) asserted that computer experience is gaining wide recognition as crucial component of the educational process.

Anxiety by definition is intense dread, apprehension, or worry. Computer anxiety as defined by Carlson and Wright (1993) is the fear of impending interaction with a computer that is disproportionate to the actual threat presented by the computer. Computer anxiety is a concept specific anxiety type, which regularly occurs in a specific type of situation (Harris \& Grandgenett, 1997). Computer anxiety has been associated with decrease use and worse, avoidance of information technology. Avoidance can seriously affect some students' academic progress, lower performance in business settings and ultimately affect career opportunities (Brown \& Vician, 1997). Those who have computer anxiety may experience fear of the unknown, feeling of frustration, possible embarrassment, failure and disappointment (Fajou, 1997).

Deloaghry (1993) stated that increased computer use may not necessarily eliminate anxiety from all computer anxious users. Kadijevich (2002) noted that due to the lack of training and experience even when computers are available, mathematics teachers rarely use them in their educational practice. Limited computer experience has been found to be a factor that 
influences anxiety (Gressard \& Loyd, 1986). Lack of training and experience is also believed to be, in part, the reason why many teachers have not been well disposed to computers and consequently deprived of their usefulness in the classroom (Collins, 1996). Computer-literate teachers with computer experience will be less inclined to doubt the usefulness of the computer in their classroom. Thus, the perceived usefulness of computers clearly influences attitudes toward computers. However, the amount of confidence a teacher possesses in using computers also influences the implementation of acquired skills in the classroom (Gressard \& Loyd, 1986; Kadijevich, 2002).

Though computer technology is not a substitute for quality teaching and learning, yet there is need for conscious efforts to utilise computers effectively to enhance teaching and stimulate students' interest in learning. Most of the research on technology-related anxiety has been conducted in the area of computer anxiety and using computers as programme or instructional management tools for teacher's use (Fletcher \& Deeds, 1994). Also many studies have only focused on factors that influence attitudes toward computer technology (Torkzadeh \& van Dyke, 2001; 2002). More recent literature should be added and integrated in this secition. Many factors have been reported to influence test anxiety. For example, Doyle, Stamouli and Huggard, (2005) found that computer anxiety decreases with increasing experience and knowledge of computer. Computer anxiety also manifests in students irrespective of their level of education. Glaister (2009) found that students who reported medium and high levels of computer anxiety performed less well than those with low level in a nursing examination involving the use of computer. However, Tekinarslan (2008) reported there is no significant difference between male and female student computer anxiety. He further indicated that while students' computer experience and knowledge increase, computer anxiety level decreases.

In Nigeria, many public and private schools lack enough computer systems to teach and train students. Most research reports and literature review on computer education continue to come from developed countries. Many teachers are yet to incorporate ComputerAssisted Instruction in teaching. Many students who do not have access to internet facilities in school make use of commercial internet centres (cyber cafés) outside the school. There is the need to carry out research on fundamental variables in computer education such as computer knowledge, anxiety and utilization in Nigeria. This study therefore investigated influence of computer knowledge and anxiety on senior secondary school student computer utilization in Ogun State, Nigeria. 


\section{Research Questions}

1. To what extent would computer anxiety and computer knowledge jointly predict students' utilization of computer?

2. What is the strength of causation of each of the independent variables (computer anxiety and knowledge) on students' utilization of computer?

3. Is there any significant relationship among computer anxiety, knowledge and students' utilization of computer?

4. Is there any significant difference between male and female students' utilization of computer?

5. Is there any significant difference between male and female student computer anxiety?

6. Is there any significant difference between male and female student computer knowledge?

\section{Method}

\section{Participants}

The target population of this study consists of all Senior Secondary School Three (S.S.S3) students in Ogun State, Nigeria. The average age of students at this level is approximately 17. Twenty Senior Secondary Schools were randomly selected from the four major zones of Ogun State namely Egba, Ijebu, Remo and Yewa. Five schools from each zone were selected. Twenty students were selected using simple random sample technique from each of the twenty schools. Four hundred (400) questionnaires were administered. Students at this level have been exposed to computer lessons in their schools and/or internet centres outside the school. How many schools and students total in the area? What type of schools are they scuh as rual, urban?

\section{Instruments}

Three questionnaires were used in this research. They are Computer Anxiety Questionnaire (CAQ), Computer Knowledge Questionnaire (CKQ) and Computer Utilization Questionnaire (CUQ). The instruments were self-designed after consulting literature on the variables in the study. The researcher took into consideration the peculiarities of Nigerian 
students. The instruments were given to experts in questionnaire construction and computer education to ensure simple sentence structure, clarity and appropriateness of statements in the instruments.

This questionnaire was divided into two sections. Section A was on personal information about the respondents such as Local Government Area, name of school, class, type of school, sex and age.

Section B: This was on Computer Anxiety. It contained 20 items which sought information on computer anxiety. A four-point Likert scale was used in this section. For each item, respondents were asked to tick the column that matches their feelings. The options are: SA $=$ Strongly Agree, $\mathrm{A}=$ Agree, $\mathrm{D}=$ Disagree and $\mathrm{SD}=$ Strongly Disagree.

Table 1. Examples of items on CAQ

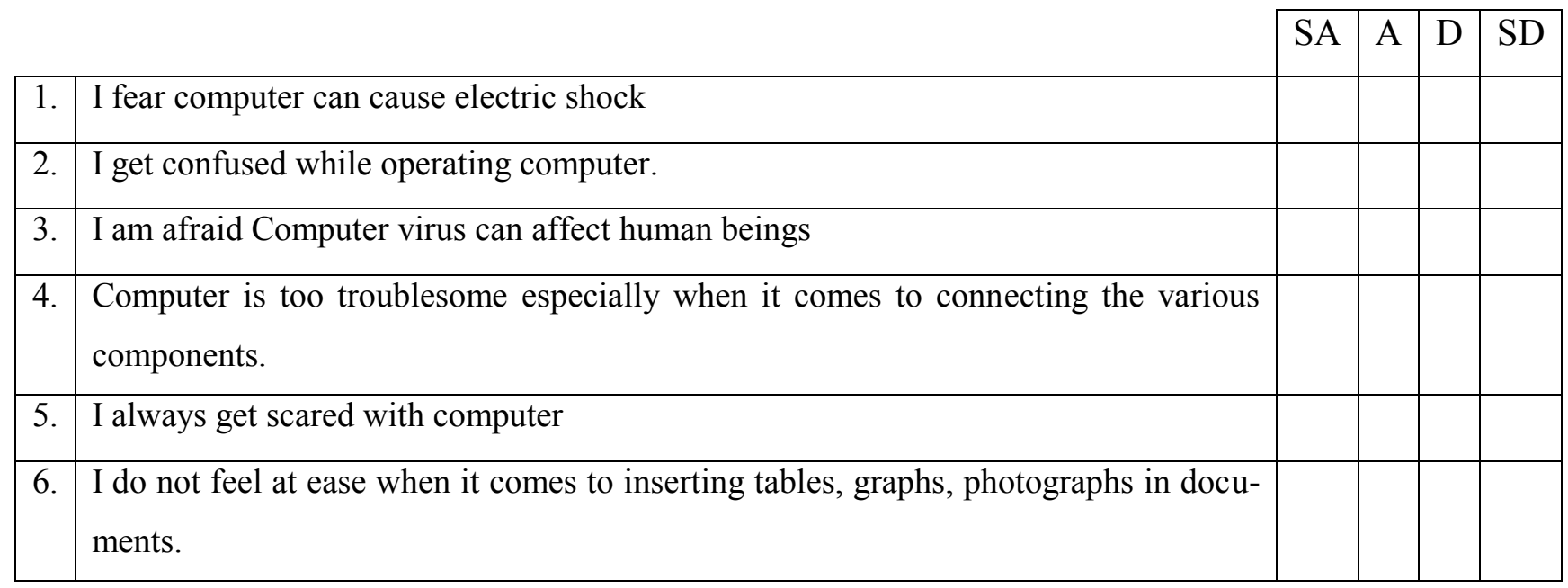


$C K Q$ comprised 20 items. It was a multiple-choice objective test with options A to D. Examples of items on CKQ:

Choose the correct option from A to D to answer the following questions.

1. The brain of computer is called.
(a) Output Unit
(b) Input Unit
(c) Memory Unit
(d) Central Processing Unit.

2. An examples of output devices is
(a) monitor
(b) processor
(c) mouse
(d) keyboard

3. A thermometer is an device.
(a) hybrid
(b) analogue
(c) digital
(d) serial

4. is an unprocessed fact.
(a) Concept
(b) Information
(c) Data
(d) Collection

CUQ comprised 20 items of which the respondents were to indicate how often frequently they carry out listed operations using computer. It was a four-point scale with the following options to the items: Very frequently, Frequently, Sometimes and Never

Instruction: Please indicate how often do you carry out the following operations using computer

Table 2. Examples of items on CUQ:

\begin{tabular}{|c|c|c|c|c|c|}
\hline & Very Frequently & Frequently & Sometimes & Never \\
\hline 1. & Word processing & & & & \\
\hline 2. & Playing games & & & & \\
\hline 3. & Surfing / browsing the internet & & & & \\
\hline 4. & Down load from the internet & & & & \\
\hline
\end{tabular}

The three instruments (CAQ, CKQ and CUQ) used in this study were developed and validated in 2009 by the researcher and trial tested on a sample of similar of students who did not participate in the major study. However, the initial versions of the instruments were given to experts for suggestions and comments before coming up with the final versions. The ex- 
perts are researchers in education and experienced teachers in computer education. The expert suggestions were considered item by item bearing in mind relevance and simplicity of each item to the variable being measured. All these steps were taken to ensure content validity of the instruments. This is to ensure that the instruments measure what they are supposed to measure.The Cronbach alpha reliability co-efficients of $0.742,0.761$ and 0.786 were obtained for CAQ, CKQ and CUQ respectively.

\section{Procedure for Data Collection}

The instruments were administered personally to the respondents in selected Senior Secondary School and collected on the same day. In administering the instruments necessary precautions were taken by the researcher to erase any form of anxiety or subjectivity on the part of the respondents. The respondents were assured utmost confidentially by the researcher. Respondents were given ample time to read through the information while the researcher was available to clarify any necessary issues. Four hundred (400) questionnaires were administered. The response rate was hundred percent because the researcher collaborated with the teachers in the various schools used for the study to ensure successful administration of instruments.

\section{Research Design and Data Analysis}

Research design is a plan or blue print which specifies how data relating to a given problem should be collected and analyzed. Research design that was applied in this study is ex-post facto research design which is a form of systematic empirical inquiry in which the researcher does not have direct control of the independent variables. They are assumed to have already occurred.

Data collected were analyzed using regression analysis, t-test and Pearson productmoment correlation. Regression analysis was used to provide answer to research question one and two, Pearson product-moment correlation was used to answer research question three while student t-test was used to answer research questions four, five and six. All research questions were answered at 0.05 level of confidence using a two-tailed test. 


\section{Results}

Data were analysed using Statistical Package for Social Science (SPSS).The research questions earlier presented are now answered one after the other.

Research Question 1: To what extent would computer anxiety and computer knowledge taken together predict students' utilization of computer?

Table 3 shows that computer anxiety and computer knowledge when taken together significantly predict computer utilization $\left(\mathrm{F}_{(2,399)}=16.9 ; \mathrm{p}<0.05\right)$. This means that computer anxiety and knowledge combined to predict computer utilization. The regression model also revealed that computer anxiety and knowledge jointly contributed $7.9 \%$ to the variation in computer utilization among students $\left(\mathrm{R}^{2}=.079, \mathrm{p}<0.05\right)$. Computer anxiety and knowledge are therefore important factors that can enhance computer utilization.

Table 3. Joint prediction of computer utilization by computer anxiety and computer knowledge

\begin{tabular}{lllllll}
\hline Model & Sum of squares & Df & Mean square & $\mathrm{F}$ & $\mathrm{p}$ & Remarks \\
\hline Regression & 3559.22 & 2 & 17779.61 & & & \\
Residual & 41751.61 & 379 & 105.16 & 16.9 & .000 & *Significant \\
Total & 45310.83 & 399 & & & & \\
\hline $\mathrm{R}=0.280$ & $\mathrm{R}^{2}=0.079$, & Adjusted R Square $=0.074$, & Standard Error $=10.25$ \\
*Significant $(\mathrm{p}<0.05)$ & & & &
\end{tabular}

Research Question 2: What is the strength of causation of each of the independent variables (computer anxiety and knowledge) on students' utilization of computer?

Table 4. Strength of causation of the predictive variables (computer anxiety and knowledge) on computer utilization

\begin{tabular}{crccccc}
\hline Model & B & $\begin{array}{c}\text { Standard } \\
\text { error }\end{array}$ & $\begin{array}{c}\text { Standard co-efficient } \\
\text { Beta }\end{array}$ & t & p & Remark \\
\hline Constant & 32.76 & 2.983 & & 10.984 & .000 & \\
Computer anxiety & .063 & .063 & .048 & 0.995 & .321 & Not significant \\
Computer knowledge & .785 & .137 & .277 & 5.743 & .000 & Significant \\
\hline
\end{tabular}

Not significant $(\mathrm{p}>0.05)$, Significant $(\mathrm{p}<0.05)$ 
Table 4 shows the strength of causation otherwise known as path co-efficients as measured by beta values. Computer anxiety does not significantly predict utilization of computer while computer knowledge significant predicts computer utilization.

Research Question 3: What are the relationships among computer anxiety knowledge and students utilization computer?

Table 5 shows that there is no significant relationship between computer anxiety and computer utilization $(\mathrm{r}=-0.045 ; \mathrm{p}>.050$ while there is significant relationship between computer knowledge and computer utilization $(\mathrm{r}=+0.276 ; \mathrm{p}<.05)$. This means that only computer knowledge have significant positive correlation with computer utilization.

Table 5. Relationship among computer anxiety, knowledge and utilization

\begin{tabular}{ll|l|l|l}
\hline Correlations & $\begin{array}{l}\text { Computer } \\
\text { anxiety }\end{array}$ & $\begin{array}{l}\text { Computer } \\
\text { knowledge }\end{array}$ & $\begin{array}{l}\text { Computer } \\
\text { utilization }\end{array}$ \\
\hline Computer anxiety: & $\begin{array}{l}\text { Pearson correlation } \\
\text { Sig. (2-tailed) }\end{array}$ & 1.000 & & \\
$\mathrm{~N}$ & 400 & & \\
\hline Computer knowledge: Pearson correlation & -0.011 & 1.000 & \\
Sig. (2-tailed) & 0.821 & & \\
$\mathrm{~N}$ & 400 & 400 & \\
\hline Computer Utilization: Pearson correlation & 0.045 & $0.276^{*}$ & 1.000 \\
Sig. (2-tailed) & 0.372 & 0.020 & \\
$\mathrm{~N}$ & 400 & & 400 \\
\hline
\end{tabular}

* Significant $(\mathrm{p}<0.05)$

Research Question 4: Is there any significant difference between male and female students' utilization of computer?

Table 6. Difference between male and female students' computer utilization

\begin{tabular}{lccccccc}
\hline Group & N & Mean & S.D & Df & t & p & Remark \\
\hline Male & 196 & 46.21 & 9.50 & 398 & 5.09 & 0.000 & Significant \\
Female & 204 & 40.9 & 11.07 & & & & $\mathrm{p}<0.05$ \\
\hline
\end{tabular}


Table 6 shows that there is a significant difference between male and female students with regards to computer utilization $(\mathrm{t}=5.09 ; \mathrm{p}<0.05)$. This means that both male and female students differ in the use of computer. Male students use computers more frequently than their female counterparts.

Research Question 5: Is there any significant difference between male and female student computer anxiety?

Table 7. Difference in male and female students' computer anxiety

\begin{tabular}{lccccccc}
\hline Group & N & Mean & S.D & Df & t & p & Remark \\
\hline Male & 196 & 40.77 & 6.38 & 398 & 1.005 & 0.315 & Not Significant \\
Female & 204 & 39.95 & 9.50 & & & & $\mathrm{p}>0.05$ \\
\hline
\end{tabular}

Table 7 shows that there is no significant difference between male and female students' computer anxiety $(\mathrm{t}=1.005 ; \mathrm{p}>0.05)$. This means that both male and female students express the same level of computer anxiety.

Research Question 8: Is there any significant difference between male and female student computer knowledge?

Table 8. Difference in male and female students' computer knowledge

\begin{tabular}{lccccccc}
\hline Group & $\mathbf{N}$ & Mean & S.D & Df & t & p & Remark \\
\hline Male & 196 & 11.72 & 3.72 & \multirow{2}{*}{398} & 3.366 & 0.001 & Significant \\
Female & 204 & 9.878 & 2.59 & & & & $\mathrm{p}<0.05$ \\
\hline
\end{tabular}

Table 8 shows that there is a significant difference between male and female students' computer anxiety $(\mathrm{t}=3.366 ; \mathrm{p}<0.05)$. This means that male students have better knowledge of computers than their female counterparts.

\section{Discussion and conclusions}

The results reveal that computer anxiety and computer knowledge when taken together significantly predict computer utilization. The result is in support of the view of Nickerson 
(1981) that the causes of resistance to computer use are not unconnected with feelings of stupidity, fear of obsolescence, fear of the unfamiliar operations done with computers and the thought that computers have a dehumanizing effect. Studies have shown that computer anxiety, lack of confidence and lack of enjoyment influence both acceptance of computers and their use as a teaching and learning tool (Gressard \& Loyd, 1986; Fletcher \& Deeds, 1994).

Loyd and Gressard (1984) opined that, it is becoming increasingly evident that familiarity with computers and the ability to use them effectively will be of critical importance to success in many different fields. Computer experience is therefore gaining wide recognition as a crucial component of the educational process. The amount of confidence a teacher or a student possesses in using computers also influences the demonstration of acquired skills in the classroom (Gressard \& Loyd, 1986).

The results also reveal that there is no significant relationship between computer anxiety and computer utilization, while there is significant relationship between computer knowledge and computer utilization. The results also support the view of Kotrlik and Smith (1989) that there is no significant difference in computer anxiety and utilization of agricultural science teachers. Collins (1996) reported that level of computer skills was a significant explanatory variable of computer anxiety. In addition, Kotrlik and Smith (1989) found that no difference existed in computer anxiety among teachers from various vocational fields. Adebanjo (2004) reported that female students showed greater anxiety in the use of computer than their male counterparts.

There is significant relationship between computer knowledge and computer utilization. There is significant difference between male and female students with regards to computer utilization. Male students use computers more frequently than their female counterparts. Shashaani (1997) observed that female students are less interested in computer and less confident in computer operation than male students. Adebanjo (2001) noted that the wrong perception of science and technology as male-oriented course by the society is still affecting female participation in computer-related activities. However, Adebanjo (2004) reported no significant difference in male and female students' attitude to computer. More recent literature should be added and integrated in this secition. 
Tekinarslan (2008) reported there is no significant difference between male and female student computer anxiety. He further indicated that as students' computer experience and knowledge increase, computer anxiety level decreases. According to Carlson, Tegen, Langan and Friedman (1999), low computer anxiety and good knowledge of computer determine how many participants benefit from training programmes involving the use of computer. Wallace and Clariana (2005) asserted that gender factor is a serious factor in computerized testing. They noted already existing gap between male and female students' utilization of computers could widen as a result of computerized testing. However, computer anxiety can be lowered and user confidence increased through training. Hoxmeir, Nie, Purvis (2000) reported that gender difference that existed between male and female participants before the commencement of a computer training programme diminished considerably at the end of training and exposure to computer activities.

Doyle, Stamouli and Huggard, (2005) found that computer anxiety decreases with increasing experience and knowledge of computer. Computer anxiety also manifests in students irrespective of their level of education. Glaister (2009) found that students who reported medium and high levels of computer anxiety performed less well than those with low level in a nursing examination involving the use of computer. Computer anxiety is a negative psychological construct that does not in anyway enhance computer utilisation. Computer knowledge however has positive relationship with computer utilization. Thus for Nigerian government to realise the Millennium Development Goals and improve computer literacy level, there is a need to deliberately encourage computer teaching, sensitise students on application of computers so that they will appreciate computers and therefore get motivated to use them. School counsellors and computer teachers need to disabuse the mind of students and all computer learners on all they have erroneously believed about computers. The computer educators should also emphasise the flexibility and wide applications of computers and availability of user-friendly computer training manual soft wares. Also, governments at all levels should provide computer systems for student use in schools. Adequate training in the use of computer tools should be stressed in the curriculum of the teacher-trainees and government should make provision for enough computers in schools.

The world is now a global village, for graduates of any country to compete favourably with their counterparts elsewhere in the world, it is imperative that such graduates should not only be computer literate but should be versatile in the use of Information Communication 
Technology. This can only be achieved if students are exposed to computer early.This will help overcome all forms of anxiety with computer use.To achieve this, international organisations and donor agencies should be involved in developing and supporting strategies that will enhance computer literacy in schools. 


\section{References}

Adebanjo, A. A. (2001). Computer literacy among the lecturers in University of Ibadan, an Unpublished M.Ed Project, University of Ibadan,Ibadan.

Adebanjo, A. A. (2004). The attitude and gender difference in the utilization of computer among undergraduates. Nigeria Journal of Computer Literacy, 5(1), 171-183.

Backer, T.E. (1994).Readiness for change, educational innovations and educational reform. Final draft of a report prepared for the U.S Department of Education, Office of Educational research and Improvement. Los Angeles: Human Interaction Research Institute.

Bandura, A. (1986). Social Foundation of Thought and Action: A Social Cognitive Theory. Englewood Cliffs, NJ: Prentice-Hall.

Brown, S.E. \& Vician, C. (1997). An Examination of the relationship between Computer Anxiety, Communication Apprehension and Student Experiences with Electronic Mail. www.springerlink.com/index/3777274050w6k6275.pdf. Retrieved from the net 11 November, 2008).

Carlson, A. M., Tegen A, Langan P., Friedman, F., (1999). Estimating Computer anxiety and skills among hospital-based health care personnel. Abstract Book of Association of Health Services Research Meeting, 16, 412-3.

Carlson, R.E. \& Wright, D.G.(1993).Computer Anxiety and communication apprehension relationship and introductory college courseeffects. Journal of Education Computing Research, 9(2),329-338.

Chiemeke, S.C. (2004).Gender and Information Technology in Nigeria, Nigerian Journal of Computer Literacy, 5(1), 159-170.

Collins, T. Jr. (1996). The effects of computer-assisted algebra instruction on achievement, mathematics anxiety levels and attitudes toward personal use of students in a historically black University. PhD Thesis, University of South Florida.

Deloughry, T.J (1993). Two Researchers say Technophobia May Afflict Millions of Students. The Chronicle of Higher Education (28 April): A 25-A26.

Doyle, E., Stamouli, I. Huggard, M. (2005). Computer anxiety, self-efficacy, computer experience: An investigation throughout a computer science degree, Frontiers in Education, 19(22), 1-3.

Fajou, S. (1997).Computer Anxiety, Journal of Education Computing Research, 17(4), 90101. 
Fernandez-Castillo, A., Gutierrez, M.E. (2009).Selective attention, anxiety, depressive symptomatology and academic performance in adolescents. Electronic Journal of Research in Education Psychology, 17, 7(1), 49-76.

Fletcher, W.E, \& Deeds, J.P.(1994).Computer anxiety and other factors preventing computer use among United States secondary agricultural educators. Journal of Agricultural Education, 35(2), 16-21.

George, P. (2000). Breaking ranks. Principal Leadership, 1(4), 56-61.

Glaister, K. (2009). The presence of mathematics and computer anxiety in nursing students and their effects on medication dosage calculations, Nurse Education Today, 27 (4), 341-347.

Gressard, C.P \& Loyd B.H (1986): The nature and correlates of Computer Anxiety in college students. Journal of human behaviour \& Learning, 2(2), 45-52.

Harris, J. \& Grandgenett, N. (1997) Writing Apprehension, Computer Anxiety and Telecomputing: A pilot study'.www.lrs.ed.uiuc.edu/mining, Retrieved 29 September, 2008

Hoxmier, J. A., Nie, W., Purvis, G. T. (2000). The impact of gender and experience on user confidence in electronic mail: Industry trend or Event, Journal of End User Computing.7(2),99-106

Jonah, I. (2007). Unlocking Internet-based business opportunities; The Punch, Pg. 4, June 26.

Kadijevich D,J (2002). Four Critical Issues of Applying Educational Technology Standards to Professional Development of Mathematic Teachers. Proceeding of the $2^{\text {nd }}$ international conference on the teaching of mathematics. Held at the undergraduate level University of Crete.

Kotrlik, J. W., \& Smith, M.N. (1989).Computer anxiety levels of vocational agriculture and other vocational teachers. Proceedings of National Agriculture Education Research Meeting, 1-9.

Loyd,B.H. \& Gressard,C.(1984).The effects of sex ,age and computer experience on computer attitudes.AEDS Journal,18(2),67-77.

Nickerson, R.S. (1981). Why Interactive Computer Systems are sometimes not used by People Who Might Benefit from Them. International Journal of Man-machine Studies, 15(4), 469-483.

Ruiz, E. F. \& Lupianez, J. L. (2009).Detecting psychological obstacles in teaching and learning the topics of reason and proportion in sixth grade pupils. Electronic Journal of Research in Education Psychology, 17, 7(1), 397-424. 
Scandroglio, B. \& Lopez-Martinez, J., \& Jose, M. C. S. (2008).Gang: Group of young people and deviant behaviour-The psychological perspective in analysis and intervention. Electronic Journal of Research in Education Psychology, 14, 6(1), 65-94.

Shashaani, L. (1997). Gender differences in computer attitudes and use among college students, Journal of Educational Computing Research, 16(1), 37-51.

Shinn, G.(2001).Communicating technology for learning: New tools and proven strategies. The Agricultural Education Magazine, 73(4), 4-9.

Tekinarslan, E. (2008). Computer anxiety: A cross-cultural study of Dutch and Turkish University students, Computers in Human Behaviour, Volume 24, Issue 4, Pp 1572 1584.

Torkzadeh, G, \& van Dyke, T.P. (2001). Development and validation of an internet selfefficacy scale. Behaviour \& Information technology, 20(4), 275.

Torkzadeh, G., \& van Dyke, T.P. (2002). Effects of training on Internet self-efficacy and computer user attitudes. Computers in Human Behavior, 18(5) 479.

Wallace, P. \& Clariana, R. B. (2005). Gender difference in computer-Administered versions Paper-based Tests. International Journal of Instructional Media 32, 37-45. 
Rafiu Ademola Olatoye

[This page intentionally left blank] 